\title{
PROBLEMA BIDANG PERTANIAN
}

\begin{abstract}
A.Sry Aska Resky
Mahasiswa Fakultas Ekonomi dan Bisnis Islam Universitas Islam Negeri Alauddin Makassar

email :andi.askaresky@gmail.com
\end{abstract}

\begin{abstract}
This writing aims to determine the elements that determine the continuity of agricultural activities such as human labor and skills, agricultural production tools, agricultural production facilities (saprodi) and agricultural land. The root of the problem in agriculture is the problem of land tenure. Methods This article uses search sestem information (information searching behavior) is done by the behavior of the information seekers to interact with all types of information systems. The results of this article get information about the lives of farmers in Indonesia and also the various obstacles they have who still do not own agricultural land as well as solutions to the capitalism economic system and the impact of the capitalist economic system and solutions to the Islamic economic system.
\end{abstract}

Keywords: land, agriculture, Islamic economy 


\begin{abstract}
Abstrak
Penulisan ini bertujuan untuk mengetahui unsur yang menentukan berlangsungnya aktivitas pertanian seperti tenaga dan keterampilan manusia, alat produksi pertanian, sarana produksi (saprodi) pertanian dan lahan pertanian. Akar masalah di bidang pertanian adalah problem penguasaan lahan. Metode artikel ini menggunakan sestem pencarian informasi (information searching behavior) merupakan perilaku yang dilakukan oleh pencari informasi dalam berinteraksi dengan segala jenis sistem informasi. Hasil artikel ini mendapatkan informasi tentang kehidupan para petani di Indonesia dan juga berbagai kendala mereka yang masih belum memiliki mempunya milik lahan pertanian juga solusi sistem ekonomi kapitalisme dan dampak sistem ekonomi kapitalisme dan solusi sistem ekonomi islam.
\end{abstract}

Kata kunci : lahan, pertanian, ekonomi islam

\title{
Pendahuluan
}

Penduduk Indonesia masih menggantungkan hidupnya dari usaha disektor pertanian. Sebagian besar penduduk Indonesia masih tinggal di perdesaan dan bekerja sebagai petani, baik sebagai petani pemilik tanah pertanian maupun sebagai penggarap tanah atau buruh tani. Namun sayangnya kebanyakan petani Indonesia adalah petani yang tidak mempunyai tanah. Kalaupun mempunyai tanah pada umumnya hanya memiliki atau menguasai tanah yang sangat sempit atau bahkan sama sekali tidak mempunyai tanah pertanian. Seyogyanya ketika seseorang mempunyai mata pencaharian sebagai petani, maka idealnya petani dimaksud mempunyai lahan pertanian yang luasnya cukup memadai. Sebab dari usaha tani itulah seorang petani akan memenuhi kebutuhan hidupnya, seperti kebutuhan sandang, pangan, papan, termasuk untuk biaya pendidikan anak-anaknya. Dengan luasan lahan pertanian yang memadai maka dapat mengangkat status sosial yang akan mensejajarkan pekerjaan petani dengan profesi yang lainnya, seperti Pegawai Negeri, pengusaha, dan lainlain, yang pada akhirnya pemerataan kesejahteraan antar sektor dan antar profesi akan dapat terwujud. kenyataannya, komoditas pertanian tidak pernah menjadi penyangga utama dari 
perekonomian Indonesia. Sektor pertanian juga tidak pernah menempatkan produk pertaniannya sebagai primadona komoditas ekonomi dilndonesia. Nasib para petani di Indonesia tidak semakin sejahtera, bahkan sebaliknya semakin lama semakin terpuruk. karena Penguasaan lahan pertaniannya semakin menyempit, bahkan tidak sedikit yang akhirnya kehilangan kepemilikan lahan pertanian dan berubah menjadi buruh tani.

\section{Asas Dalam Bidang Pertanian}

Ada 4 unsur yang menentukan berlangsungnya aktivitas pertanian sebagai berikut :

1. Tenaga dan keterampilan manusia.

Keterampilan adalah kemampuan seseorang dalam mengubah sesuatu hal menjadi lebih bernilai dan memiliki makna. Menggunakan keterampilan bisa saja dengan pikiran, akal dan kreatifitas. Jika keterampilan itu diasah, tidak menutup kemungkinan bila akan menghasilkan sesuatu yang menguntungkan. Menurut Gordon (1994) Keterampilan merupakan sebuah kemapuan dalam mengoperasikan pekerjaan secara lebih mudah dan tepat. Definisi keterampilan menurut Gordon ini cenderung mengarah pada aktivitas psikomotor. keterampilan setiap orang harus diasah melalui program training atau bimbingan lain. Training dan sebagainya pun didukung oleh kemampuan dasar yang sudah dimiliki seseorang dalam dirinya. Jika kemampuan dasar digabung dengan bimbingan secara intensif tentu akan dapat menghasilkan sesuatu yang bermanfaat dan bernilai bagi diri sendiri dan orang lain.

Keterampilan petani yang dimaksud adalah keterampilan yang dimiliki oleh petani dalam bertani, yaitu keterampilan yang sifatnya keahlian, keterampilan di sini bersumber dari pengalaman pribadi yang dimiliki oleh petani yang terdiri dari pengolahan lahan, pembibitan, penanaman, pemeliharaan, pengairan dan pemanenan (Hamrat 2018).

2. Alat produksi pertanian.

Penggunaan mesin pertanian merupakan salah satu cara untuk meningkatkan produktivitas dan efisiensi usaha tani, meningkatkan mutu dan nilai tambah produk, serta pemberdayaan petani. Pada hakekatnya, penggunaan mesin di pertanian adalah untuk meningkatkan daya kerja manusia dalam proses produksi pertanian, di mana setiap tahapan dari proses produksi tersebut dapat menggunakan alat dan mesin pertanian (Sukirno 1999). Dengan demikian, mekanisasi pertanian diharapkan dapat meningkatkan efisiensi tenaga manusia, derajat dan taraf hidup petani, kuantitas dan kualitas produksi pertanian, 
memungkinkan pertumbuhan tipe usaha tani dari tipe subsisten (subsistence farming) menjadi tipe pertanian perusahaan (commercial farming), serta mempercepat transisi bentuk ekonomi Indonesia dari sifat agraris menjadi sifat industri (Wijanto 2002). ${ }^{1}$

Alsintan pada saat ini telah menjadi kebutuhan dalam pelaksanaan budi daya pertanian mengingat ketersediaan tenaga kerja pertanian yang sudah semakin menurun, karena kalangan muda enggan terjun ke sektor pertanian. Upah tenaga kerja yang mahal diatasi dengan mekanisasi pertanian.

3. Sarana produksi (saprodi) pertanian.

Sarana produksi pertanian adalah segala jenis peralatan, perlengkapan dan fasilitas pertanian yang berfungsi sebagai alat utama atau pembantu dalam pelaksanaan produksi pertanian. Sarana produksi berperan penting di dalam usaha mencapai produksi sesuai dengan tujuan yang diinginkan. Sarana produksi pertanian atau saprotan terdiri atas bahan yang meliputi benih, pupuk, pestisida dan zat pengatur tumbuh. Sarana -sarana tersebut sudah harus tersedia sebelum memulai kegiatan budidaya tanaman.

\section{Lahan pertanian.}

Lahan adalah suatu wilayah daratan bumi yang ciri-cirinya mencakup semua tanda pengenal (attributes) atmosfer, lahan, geologi, timbulan (relief), hidrologi dan populasi tumbuhan dan hewan, baik yang bersifat mantap maupun yang bersifat mendaur, serta hasil kegiatan manusia masa lalu dan masa kini, sejauh hal-hal tadi berpengaruh (significant ) atas penggunaan lahan pada masa kini dan masa mendatang. Menurut Notohadikusumo (2005), lahan adalah jabaran operasional kawasan. Lahan (land) ialah hamparan darat yang merupakan suatu keterpaduan sejumlah sumberdaya alam dan budaya. Lahan mengandung sejumlah ekosistem dan sekaligus juga menjadi bagian dari ekosistemekosistem yang dikandungnya. ${ }^{2}$

Penggunaan lahan yang merupakan tuntutan bagi manusia sebagai penopang hidup, menjelaskan bahwa alih fungsi lahan merupakan hal yang lazim dan harus terjadi. Hal tersebut didukung dengan kegagalan institusional, di mana pelaksanaan peraturan-peraturan

\footnotetext{
${ }^{1}$ Qori Fadillah, "Pengaruh Alat Mesin Pertanian Secara Economis Untuk Meningkatkan Efisiensi Pengolahan Tanah Di Djati Gede Sumedang", Fakultas Sains dan Teknologi, Uin Sunan Gunung Djati Bandung, 2018, hal 3.

2 Kadek Dwi Andika, “Faktor-Faktor Yang Mempengaruhi Konversi Lahan Pertanian Dan Hubungannya Terhadap Kesejahteraan Petani Subak Saih Di Kecamatan Kuta Utara, Kabupaten Badung" Dalam Manajemen Agribisnis, (Bali: Universitas Udayana, 2017), hal 2.
} 
atas sumber agraria masih lemah, serta kurang jelas batasan-batasan peruntukan lahan. Faktor-faktor tersebut turut mempengaruhi konversi lahan.

Bagi petani, lahan mempunyai arti yang sangat penting. Dari situlah mereka dapat mempertahankan hidup bersama keluarganya, melalui kegiatan bercocok tanam dan berternak. Karena lahan merupakan faktor produksi dalam berusaha tani, maka keadaan status penguasaan terhadap lahan menjadi sangat penting. Ini berkaitan dengan keputusan jenis komoditas apakah yang mau diusahakan dan juga berkaitan dengan besar kecilnya bagian yang akan diperoleh dari usahatani yang diusahakan.

\section{Akar Masalah Bidang Pertanian}

Persoalan lahan pertanian senantiasa menjadi problem yang tiada pernah ada habisnya. Bahkan bisa dikatakan, sepanjang sejarah manusia, problem penguasaan lahan pertanian senantiasa mewarnai dinamika kehidupan umat manusia. Penjajahan negara, peperang besar antar negara, perang antar penduduk kampung dan kampung sebelah, juga tidak terlepas dari persoalan lahan pertanian.Termasuk di Indonesia, berbagai kerusuhan akibat persengketaan lahan pertanian, terus-menerus mewarnai kehidupan, baik itu persengketaan antar individu,antar kelompok maupun antar perusahaan dengan masyarakat, antar negara dengan perusahaan, maupun antar negara dengan masyarakat.

\section{Solusi Sistem Ekonomi Kapitalisme}

Pandangan sistem ekonomi kapitalisme dalam pengaturan penguasaan lahan pertanian yaitu Setiap individu bebas untuk memiliki lahan pertanian.Setiap individu bebas untuk memanfaatkan lahan pertaniannya, untuk ditanami apapun juga.dan juga Setiap individu bebas untuk mengembangkan dan memperbesar kepemilikan lahan pertaniannya.

\section{Dampak Sistem Ekonomi Kapitalisme}

a) Munculnya persaingan bebas dalam kepemilikan lahan pertanian.

Aspek penguasaan dan pemilikan jelas berbeda dengan aspek penggunaan dan pemanfaatan, karena yang pertama berkenaan dengan bagaimana relasi hukum manusia dengan lahan, sedangkan yang kedua membicarakan bagaimana lahan (dan sumberdaya agraria lain) digunakan dan dimanfaatkan sebagai sumberdaya ekonomi. batasan pola-pola penguasaan lahan dengan menelaah istilah pemilikan, penguasasan, dan pengusahaan lahan. Kata pemilikan merujuk kepada penguasaan formal, sedangkan penguasaan menunjuk kepada penguasaan efektif, dalam artian mengusahakan lahan secara 
efektif. Pengusahaan menunjuk kepada bagaimana caranya sebidang lahan diusahakan secara produktif.

Untuk menguasai lahan dapat dilakukan dengan sewa, gadai, bagi hasil, dan sebagainya. Pemilik lahan sempit dapat menggarap lahan orang lain melalui sewa atau sakap, di samping menggarap lahannya sendiri. Berdasarkan cara penguasaan tersebut, maka terdapat penggolongan penduduk pedesaan sebagai berikut:

1) Pemilik penggarap murni, yaitu petani yang menggarap lahannya sendiri.

2) Pemilik dan penyakap murni, yaitu mereka yang tidak memiliki lahan tetapi memiliki garapan melalui sewa atau bagi hasil. Golongan ini termasuk ke dalam kelompok tunakisma, tetapi jika dilihat dari garapan, maka mereka termasuk pengusaha lahan efektif.

3) Pemilik penyewa dan atau pemilik penyakap, yaitu mereka yang di samping menggarap lahannya sendiri, juga menggarap lahan milik orang lain.

4) Pemilik bukan penggarap, umumnya pemilik lahan luas.

5) Tunakisma mutlak, yaitu mereka yang benar-benar tidak memiliki lahan dan tidak mempunyai lahan garapan. Sebagian besar mereka adalah buruh tani.

Fenomena pemilikan lahan terkait erat dengan pertumbuhan penduduk. Makin mengecilnya persediaan lahan rata-rata per orang, sejalan dengan pertumbuhan penduduk, mereka yang tak berlahan diperkirakan semakin bertambah (tunakisma). Dalam keadaan tekanan penduduk yang berat ini memberikan peluang bagi berkembangnya bentuk-bentuk hubungan penguasaan lahan yang kurang menguntungkan penggarap. Persaingan antara sesama buruh tani semakin sengit dalam mendapatkan kesempatan kerja (Rusli, 1995). Sihaloho (2004) mengemukakan bahwa pola penguasaan dapat diketahui pertama dari pemilikan lahan dan bagaimana lahan tersebut diakses oleh orang lain. Menurutnya, penguasaan dapat dibagi dua yaitu, pertama, pemilik sekaligus penggarap. Pemilik penggarap umumnya dilakukan oleh petani berlahan sempit, karena ketergantungan ekonomi dan kebutuhan akan rumahtangga maka pemilik sekaligus menggarap lahannya dengan menggunakan tenaga kerja keluarga dan atau memanfaatkan tenaga buruh tani. Kedua adalah pemilik yang mempercayakan kepada penggarap. Seperti ungkapan Scheltema (1985) yang dikutip oleh Sihaloho (2004), pola ini merupakan pola yang khas terjadi di Indonesia sejak tahun 1931 dan telah ditemukan di 19 daerah hukum adat. Hal ini menunjukkan ketimpangan struktur agraria telah terjadi sejak lama dan sistem bagi hasil dan atau sewa 
menjadi solusi ketimpangan ini khususnya dalam hal penguasaan dan atau akses terhadap lahan. Secara umum, konversi lahan menyebabkan perubahan struktur agraria. Perubahan ini dilihat dari pemilikan lahan yang makin sempit bagi masyarakat setempat. Konversi juga menyebabkan hilangnya akses terhadap lahan bagi petani penggarap dan buruh tani. ${ }^{3}$

b) Terjadinya ketidakseimbangan dalam penguasaan lahan pertanian.

Ketimpangan penguasaan tanah pertanian ditandai dengan petani yang memang mata pencaharian pokoknya hidup dari usaha pertanian hanya memiliki tanah yang sangat sempit atau bahkan tidak punya tanah pertanian sama sekali, tetapi pada sisi yang lain ada segelintir kelompok orang yang bukan petani atau badan hukum menguasai tanah yang sangat luas. Kondisi ini telah berlangsung cukup lama. Adanya kelompok masyarakat tertentu apapun sebutannya menyebabkan akses petani untuk menguasai tanah pertanian semakin lama semakin terbatas. Dalam kerangka memenuhi kebutuhan hidup keluarga petani dimaksud, maka petani berupaya untuk menguasai (ocupasi) lahan pertanian yang telah duikuasai oleh pelaku usaha dibidang perkebunan, tertutama perkebunan-perkebunan besar yang menguasai lahan yang sangat luas. Tindakan ini biasanya dilakukan tidak sendiri-sendiri melainkan dilakukan secara massal. Masyarakat berupaya untuk menguasai lahan perkebunan baik yang telah diolah maupun yang belum. Mereka seolah-olah telah mengabaikan norma-norma yang berlaku. Hal ini diperparah dengan sikap pemerintah yang kadang-kadang lamban didalam mencegah perilaku masyarakat dan bahkan terkesan membiarkan perbuatan tersebut berlangsung. Kondisi yang demikian ini bisa dikatakan terjadi diseluruh provinsi di Indonesia. Bahkan implikasi dari perbuatan tersebut telah menimbulkan dampak yang tidak menguntungkan bagi para pihak. Tindakan penguasaan tanah perkebunan yang telah dikusai dengan sesuatu hak yang sah oleh pihak-pihak yang tidak berhak tersebut apapun alasannya adalah perbuatan yang tidak dapat dibenarkan dan secara yuridis termasuk perbuatan yang melanggar hukum. Sebab untuk memperoleh hakhak atas tanah haruslah dilakukan berdasarkan pada alas hak dan menurut tata cara yang telah diatur dalam peraturan perundangundangan.

c) Pemilik lahan pertanian besar, akan semakin besar dan terus melakukan ekspansi untuk memperbesar kepemilikan lahannya, Petani pemilik lahan kecil akan semakin sempit

\footnotetext{
${ }^{3}$ Lailan Safina Hasibuan, “Analisis Dampak Konversi Lahan Terhadap Sosial Ekonomi Masyarakat Di Kabupaten Deli Serdang", Dosen Fakultas Ekonomi, Universitas Muhammadiyah Sumatera Utara 2015, hal 8.
} 
penguasaan lahannya, Petani-petani akan kehilangan kepemilikan lahannya dan akhirnya hanya menjadi buruh tani.

Hal ini biasanya diawali dengan peminjaman hutang yang dilakukan petani karena dianggap sebagai penolong para petani dalam menyelesaikan segala macam masalah dan kendala yang dialami. Tetapi yang terjadi justru hal ini membawa petani jatuh miskin dengan besarnya beban bunga pinjaman yang akan dibayarkan. Bunga akan terus bertambah sesuai besarnya nominal yang dipinjam, dan akan mengalami peningkatan sejalan dengan keterlambatan batas waktu pembayaran. Setelah diberikan pinjaman berupa modal awal, petani tidak pernah menyadari hal yang nantinya akan membuat petani bisa mengalami kemiskinan karena banyaknya hutang. Petani identik dengan pekerjaan yang kurang menjanjikan harapan untuk bisa hidup sejahtera, sehingga kemiskinan yang dialami petani tidak kunjung terselesaikan. Pada akhirnya petani banyak kehilangan lahan untuk menyelesaikan permasalahan yang semakin menumpuk, dan petani yang awalnya merupakan pemilik lahan beralih menjadi buruh tani. Kehidupan ekonomi semakin terpuruk dan mengalami kemiskinan. Kemiskinan merupakan kondisi yang ditandai dengan situasi ketidakmampuan dan serba kekurangan baik kebutuhan sandang, pangan, papan, kesehatan dan pendidikan.

d) Puncak adalah terjadinya feodalisme dalam bidang pertanian.

Feodalisme berasal dari kata feodum yang artinya tanah. Dalam tahapan masyarakat feodal ini terjadi penguasaan alat produksi oleh kaum pemilik tanah dan kaum kapitalis. Ada antagonisme antara rakyat tak bertanah dengan para pemilik tanah merupakan alat kalangan feodal untuk mempertahankan kekuasaan atas petani, tanah, kebenaran moral, etika agama, serta seluruh tata nilainya. Para feodal yang memiliki tanah yang luas mempekerjakan orang yang tidak bertanah yang mata pencahariaannya merupakan petani dan tidak memiliki lahan.

\section{Solusi Sistem Ekonomi Sosialisme}

Sosialisme memandang bahwa penyebab utama terjadinya ketidakadilan dalam penguasaan lahan pertanian adalah feodalisme. Solusinya adalah dapat dihapuskannya hak kepemilikan secara mutlak bagi setiap individu. Negaralah yang berperan dalam mengatur aspek produksi, penjualan, distribusi, serta penentuan upah rakyatnya dalam bidang pertanian.Sebagai sosialisme memandang hanya kepemilikan lahan produktif yang dilarang, sedangkan kepemilikan lahan konsumtif diperbolehkan. Sosialisme yang lain menganjurkan land reform (pembagian kembali secara sama seluruh lahan pertanian di suatu negara). Untuk 
menguasai atau memiliki tanah apapun statusnya telah diatur oleh hukum. Demikian juga tata cara untuk memperoleh hak tersebut haruslah dilakukan dengan cara sebagaimana yang telah diatur menurut hukum yang berlaku. Ketimpangan penguasaan tanah disebabkan karena keadilan dibidang penguasaan tanah pertanian ternyata tidak dipahami secara benar, penguasaan lahan harus dilakukan berdasarkan asas keadilan, asas manfaat, asas usaha bersama, asas persamaan hak, asas ketuhanan, asas fungsi sosial, asas tanah untuk pertanian sehingga pemilikan tanah secara guntai tidak semakin meningkat, pemilikan tanah pertanian oleh bukan petani tidak semakn bertambah, dan tanah tidak terlantar secara fisik.

\section{Dampak Sistem Ekonomi Sosialisme}

Menyebabkan produktivitas pertanian negara sosialis menjadi merosot dibanding negara Eropa yang kapitalis.Penyebabnya adalah kehilangan motivasi berproduksi dari rakyatnya, akibat dihapuskannya hak kepemilikan dan rendahnya upah buruh oleh negara.Di terapkannya sistem land reform, ternyata juga mengakibatkan keadaan yang serupa.Penghapusan hak kepemilikan dan land reform adalah tidak akan saling terhadap rakyat, karena telah mencabut hak kepemilikan lahan.

\section{Solusi Menurut Akal Manusia}

Sistem Ekonomi Kapitalisme: Kepemilikan lahan pertanian adalah bebas.

Sistem Ekonomi Sosialisme: Kepemilikan lahan pertanian ada 3 kemungkinan:

1. Kepemilikan lahan dilarang secara keseluruhan.

2. Hanya kepemilikan lahan pertanian saja yang dilarang.

3. Kepemilikan lahan pertanian dibagi rata (land reform).

\section{Solusi Sistem Ekonomi Islam}

Sistem ekonomi Islam dalam menyelesaikan dua program di bidang pertanian. Dua problem tersebut yaitu:

1. Problem feodalisme (dari sistem ekonomi kapitalisme)

2. Problem Demotivasi berproduksi (dari sistem ekonomi sosialisme)

Solusi dari sistem ekonomi Islam yang diperoleh dari metode induktif (istiqro'i) yaitu hukum syari'at yang bersifat umum, dan penyatuan kepemilikan lahan pertanian dengan produksinya.

\section{Proses Induksi (Istiqro'i)}

Solusi hukum syari'at umum di atas di induksi dari tiga hukum syari'at sekaligus, sebagai berukut: 
1. Hukum menghidupkan tanah mati (ihya'u al-mawat).

2. Hukum larangan menelantarkan lahan pertanian selama lebih tiga tahun.

3. Hukum larangan menyewakan lahan pertanian.

Dari tiga hukum Syari'at tersebut, ditarik hukum Syari'at yang bersifat umum, yaitu: penyatuan kepemilikan lahan pertanian dengan produksinya.

\section{Solusi Terhadap Dua Problem Pertanian}

a) Peningkatan produksi pertanian

Islam memberikan kebebasan bagi individu untuk memiliki lahan seberapapun luasnya, selama masih mampu memproduksi. Hal itu diharapkan tidak ada lahan kosong yang menganggur, sehingga semua lahan diharapkan akan produktif.Islam juga membebaskan pengembangan komoditas pertanian untuk menjamin terjadinya diversifikasi di bidang pertanian. Dengan adanya kepemilikan individu, produktivitas pertanian terus meningkat, karena motivasi berproduksi tetap terjaga. Problem rendahnya produktivitas, karena demotivasi berproduksi sebagaimana dalam pertanian sosialisme, dapat teratasi.

Petani sudah mulai untuk memikirkan berbagai faktor yang mempengaruhi produktivitas petani sehingga mampu memberikan penambahan nilai bagi petani itu sendiri. Mengingat permasalahan pertanian yang timbul dari kurangnya tingkat produktivitas sektor pertanian, para pelaku tani harus mulai serius dalam menangani hal tersebut dengan berbagai faktor yang mempengaruhi produktivitas yaitu pelatihan, luas lahan serta teknologi yang khusus lebih di tekankan pada penelitian ini.

Dari sisi petani produktivitaslah yang menjadi faktor penting dalam mewujudkan keberhasilan peningkatan pendapatan petani itu sendiri, selain itu juga dapat menghasilkan produk tani yang bebas dari bahan kimia yang dampaknya kerusakan alam dan lingkungan tersebut. Produktivitas juga mencerminkan etos kerja petani yang baik baik dari segi mental ataupun yang lainnya. Dengan demikian para pelaku tani yang terjun langsung berusaha untuk meningkatkan kinerjanya dengan berbagai kebijakan yang secara efisien, mampu meningkatkan produktivitasnnya. Selain itu banyak faktor yang mengakibatkan turunnya sektor pertanian yang dilihat dari produktivitasnya. Pada masalah penurunan sektor pertanian yang dipicu dari produktivitas penyebabnya tidak menentunya iklim yang menjadi alasan petani menurunnya produktivitas, selain itu juga debit air yang menurun juga menjadi kendala dalam proses pertanian berlangsung. 
Seperti yang kita ketahui lahan merupakan hal utama dalam usaha tani, sesuai dengan teori yang ada jika semakin besar luas lahan maka semakin besar produktivitas yang di hasilkan. Lahan adalah salah satu faktor produksi, tempat dihasilkannya produk pertanian yang memiliki sumbangan yang cukup besar terhadap usaha tani, karena banyak sedikitnya hasil produksi dari usaha tani sangat dipengaruhi oleh luas sempitnya lahan yang digunakan. Mengingat penurunan sektor pertanian kerena beberapa faktor yang memang menjadi kendala dalam peningkatan pada sektor pertanian diantaranya, pengalih fungsi lahan pertanian yang merupakan hal yang penting dalam meningkatkan produktivitas, selain itu pelatihan yang diberikan oleh lembaga terkait dalam sektor pertanian yang melatih para petani dalam menggunakan teknologi, serta cara-cara bertani yang benar untuk penggunaan bahan yang efisien dengan hasil yang tepat

Produktivitas dapat didefinisikan sebagai hubungan masukan-masukan dan keluarankeluaran suatu sistem produksi". Produktivitas adalah sikap mental yang mempunyai pandangan bahwa kehidupan hari ini harus lebih baik dari hari kemarin, dan hari esok harus lebih baik dari hari ini. Pertumbuhan produktivitas relatif stabil sehingga untuk meningkatkan produktivitas diperlukan gairah petani dalam membudidayakan usahataninya (Aldillah, 2015). ${ }^{4} \mathrm{Hal}$ yang paling utama dalam pertanian dan usaha tani tentu saja adalah lahan pertanian, yang mana semakin luas lahan maka semakun besar jumlah produk yang dapat di hasilkan

Lahan adalah salah satu faktor produksi, tempat di hasilkannya produk pertanian pertanian yang memiliki peran yang besar terhadap usaha yangdi geluti petani karena hasil produksi sangat dipengaruhi oleh luas sempitnya lahan. Menurut Krishna et al. (2014) yang menguji faktor-faktor yang mempengaruhi Luas Lahan dimana Hasil uji membuktikan bahwa luas tanah, irigasi, dan upah tenaga kerja merupakan faktor yang signifikan mempengaruhi produksi.

Luas lahan merupakan satu-satunya faktor yang memiliki efek yang signifikan terhadap pendapatan bulanan pada petani, jadi jika luas lahan meningkat maka pendapatan petani akan meningkat, Petani yang menyediakan lahan yang luas untuk tanamannya maka produk petani akan secara signifikan meningkat dan produktivitas juga meningkat secara siginifikan. Luas lahan juga berpengaruh signifikan terhadap produksi usahatani cengkeh

\footnotetext{
${ }^{4}$ Putu Dika Arimbawa dan A.A Bagus Putu Widanta, "Pengaruh Luas Lahan Teknologi Dan Pelatihan Terhadap Pendapatan Petani Padi Dengan Produktivitas Sebagai Variabel Intervening Di Kecamatan Mengwi", Dalam E-Jurnal EP Unud, 6[8]: 1601-162, (Bali: Universitas Udayana, 2015), hal 13.
} 
dimanggasari, selain itu juga dapat dikatakan semakin luas lahan akan berpengaruh jumlah produksi dan ekspor sehingga penawaran meningkat.

b) Pemerataan ekonomi di bidang pertanian

Adanya larangan menelantarkan dan menyewakan lahan pertanian, keserakahan dalam kepemilikan lahan dapat dicegah.Peluang bagi buruh tani untuk memiliki lahan pertanian sendiri juga akan semakin terbuka. Keterampilan (skill) petani mendapatkan penghargaan yang tinggi. Bagi pemilik lahan luas, jika tidak mampu menggarapnya, dapat mengupah petani, namun tentu dengan upah yang tinggi. Apabila tidak mau, petani tinggal menunggu 3 tahun untuk memiliki lahan yang tidak tergarap, dengan jalan menggarapnya.Problem feodalisme dapat teratasi, sehingga pemerataan ekonomi di bidang pertanian dapat diwujudkan. 


\section{Daftar Pustaka}

Aldillah, R. 2015. Kinerja Pemanfaatan Mekanisasi Pertanian Dan Implikasinya Dalam Upaya Percepatan Produksi Pangan Di Indonesia. Forum Penelitian Agro Ekonomi, Vol. 34 No. 2, 163-177.

Aldillah, Rizma. "Proyeksi produksi dan konsumsi kedelai Indonesia." Jurnal Ekonomi Kuantitatif Terapan 8.1 (2015): 44324.

Andika, Kadek Dwi, Wayan Windia, and Ketut Suamba. Faktor-Faktor Yang Mempengaruhi Konversi Lahan Pertanian Dan Hubungannya Terhadap Kesejahteraan Petani Subak Saih Di Kecamatan Kuta Utara, Kabupaten Badung.

Gordon Davis B. 1994. Management System Information. Midas Surya Grafindo: Jakarta.

Hamrat, Muthmainnah Bakri. 2018. Pengaruh Pengetahuan Keterampilan Dan Sikap Terhadap Tingkat Penerimaan Teknologi Budidaya Organik. Universitas Hasanuddin: Makassar

Hasibuan, Lailan Safina. "Analisis Dampak Konversi Lahan Terhadap Sosial Ekonomi Masyarakat di Kabupaten Deli Serdang." Jurnal Ekonomikawan 15.1 (2015): 77484.

Rusli, S. 1995. Persaingan Antara Sesama Buruh Tani Semakin Sengit Dalam Mendapatkan Kesempatan Kerja Pustaka LP3ES Indonesia: Jakarta

Sihaloho, Martua. 2004. Konversi Lahan Pertanian Dan Perubahan Struktur Agrarian. (Tesis). Institut Pertanian Bogor: Bogor.

Wijaya, W. (2020). Analisa dan Perancangan Mesin Pengupas Bawang Merah Skala Industri Perumahan (Studi Kasus Koperasi Produksi Mitra Kelapa) Sidahurip Kabupaten Pangandaran. Ensains Journal, 3(1), 28-33. 